This item was submitted to Loughborough's Research Repository by the author.

Items in Figshare are protected by copyright, with all rights reserved, unless otherwise indicated.

\title{
Everyday experiences of economic change: repositioning geographies of children, youth and families
}

PLEASE CITE THE PUBLISHED VERSION

https://doi.org/10.1111/area.12348

PUBLISHER

(c) Wiley

VERSION

AM (Accepted Manuscript)

\section{PUBLISHER STATEMENT}

This work is made available according to the conditions of the Creative Commons Attribution-NonCommercialNoDerivatives 4.0 International (CC BY-NC-ND 4.0) licence. Full details of this licence are available at: https://creativecommons.org/licenses/by-nc-nd/4.0/

\section{LICENCE}

CC BY-NC-ND 4.0

\section{REPOSITORY RECORD}

Pimlott-Wilson, Helena, and Sarah Marie Hall. 2019. "Everyday Experiences of Economic Change: Repositioning Geographies of Children, Youth and Families". figshare. https://hdl.handle.net/2134/24643. 


\title{
Everyday Experiences of Economic Change: Repositioning Geographies of
}

\section{Children, Youth and Families}

\begin{abstract}
In this paper, we argue for repositioning geographies of children, youth and families at the centre rather than at the periphery of discussions about the economy. This not only reveals what contemporary and lived experiences of economic change feel and look like, but also exposes deeper problematics about the geographically and socially uneven nature of neoliberalism and the austere state. This editorial also introduces a collection which, when taken together, explores intersections between everyday life and austerity, with children, youth and families as the focus of inquiry.

Adopting a multi-scalar approach, the collected papers 'zoom in' to explore the everyday realities of austere life in the UK in order to refract our understanding of the broader condition of economic change and concomitant austerity measures. Simultaneously, and speaking to a wider political agenda, the collection can be scaled up, or the framing 'zoomed out', to question and actively address the injustices of austerity and neoliberal retrenchment.
\end{abstract}

\section{Keywords}

Children; Austerity; Families.

Dr Helena Pimlott- Wilson

Department of Geography

Loughborough University

Loughborough

LE11 3TU, UK

h.pimlott-wilson@lboro.ac.uk

Dr Sarah Marie Hall

Geography, School of Environment, Education and Development

University of Manchester

Manchester

M13 9PL, UK

sarah.m.hall@manchester.ac.uk 


\section{Everyday Experiences of Economic Change:}

\section{Repositioning Geographies of Children, Youth and Families}

The global financial crisis of 2007-2009 has had catastrophic impacts on global, national, regional and local economic and social geographies across Europe (Pollard, 2013; Christophers, 2015). These various and often deep-felt impacts continue to play out in the form of job losses, pay cuts, precarious employment contracts and short-hours working, slashed public spending, welfare reforms and the rising cost of everyday goods and household bills. For many people affected by and living through these changes, the future remains somewhat bleak (MacLeavy, 2011; JRF, 2012).

While geographers have provided much insight into the economic impacts of austerity, particularly on governments, financial markets and businesses (Aalbers, 2009), there has been notably less concern paid to what it means to experience financial crises and how these experiences are felt at more personal and intimate scales, such as within families and households (Jensen and Tyler 2012; Hall, 2016). And yet, as Edwards and Weller (2010) also identify, attention to the impacts of the financial crisis and austerity on children, youth and families is incredibly important for what it can tell us about the lived experience of economic change.

Indeed, the impacts of austerity on children, youth and families represent an area of significant policy and public interest. In November 2012, for instance, the UK Government launched a consultation on the measurement of child poverty, moving away from principally economic assessments to include social factors; in July 2015, new legislation was announced to replace the former Child Poverty Act, including a broader array of measures of child poverty focused on social indicators such as inter-generational worklessness, family break up and school attendance (GOV.UK, 2015a). While contestable and problematic, changing the child poverty measurement in this way and in the context of a suite of austerity measures and welfare reforms (see GOV.UK, 2015b) - once 
again highlights the heavily entrenched and intimately bound ideological relationship between the state, children and families (Stacey, 1993; Oswin and Olund, 2010).

Across Europe the current climate of austerity has also seen the increasing reliance of families and individuals on food banks, and the politicisation of this space as representative of the retreat of the welfare state at a time when social support is most needed (Lambie-Mumford, 2013). The impacts of austerity further resonate within the most private of spaces and relationships, with growing numbers of young people financially dependent on their parents. Reports show that nearly half of Europe's young people are living with their parents (Malik, 2014), a trend spurred by the economic crisis and concomitant high rates of young unemployment, cuts to benefits for young people, and dwindling chances of getting on the property ladder. In the UK, these figures are set to rise further still, given recent changes to housing benefits that have removed the automatic entitlement of unemployed young people aged 18-21 to housing support, meaning all but the most vulnerable will have to continue to live at home (GOV.UK, 2015b). Despite political attention on these and other examples of economic and social upheaval in the name of 'austerity', there remains a paucity of research exploring the lived experiences of children, youth and families in austere times.

We are not alone in raising such questions and concerns about the nature and focus of current academic debates about the impacts of austerity (see Morrow, 2012; Pollard, 2013), and in this collection we build on a burgeoning body of literature that has sought to understand and interpret, as well as challenge and deconstruct, contemporary austerity discourses and politics (see Jensen and Tyler, 2012; McDowell, 2012; Pearson and Elson, 2015). Indeed, a mass of critical, dissenting voices are emerging that probe at the meanings, makings and motivations of austerity, but we think there is more to be done.

What we contribute to these debates, therefore, is a novel focus on the spaces where the everyday and the economic meet, mix and at times, collide. We illustrate the need for contemporary geographical research to reveal and expose the everyday, inner-workings of austerity as it is lived 
and experienced. We posit that understanding and unpacking these accounts is a valuable endeavour, but as yet our understandings of them are incomplete. We pay attention to the multiscalar nature of austerity and its impacts; that they are far-reaching, spatially and socially discerning, and may change over time. This includes a consideration of how economic change and policy-making play out in everyday life, but also how everyday practices and decisions 'talk back' to, and expose problems within, broader economic and political systems; a 'zooming in and zooming out' effect that allows for these multi-layered meanings and accounts.

Achieving this task, we find, also requires a certain focus, and as such this piece and the remainder of the collection focuses primarily on the UK. The UK and USA contexts of austerity are typically regarded as the breeding grounds for the increasingly-close relationship between everyday life and global finance, and when the US sub-prime mortgage crisis 'hit', the impacts quickly ricocheted through into the UK and the global financial market (Aalbers, 2009; Martin, 2011). As a result, the UK economy experienced the deepest recession since the Great Depression and the ConservativeLiberal Coalition Government introduced the biggest spending cuts since the Second World War. The UK now ranks as one of the most unequal countries in the OECD (Oxfam, 2013).

By crafting together this special issue, and in repositioning geographies of children, youth and families within geographical discussions about austerity, we aim to address the plurality of experiences of economic crisis and austerity - within and between families and communities, and encompassing geographies of class, gender and inter-generationality (see Valentine, 2003). We also wish to stress that these events take place in the context of other significant life events and personal circumstances, such as poverty, partnership dissolution and unemployment. As such, a strong narrative is hereby told of the everyday realities of contemporary austere life in the UK, and of the potential for geographers to contribute to debates in this field.

Below we specify how, in reference to both this collection and as an agenda, geographies of children, youth and families can illuminate understandings of the lived experiences of economic 
change, by addressing the relationship between the state and society, transcending spatial and temporal borders, and giving voice and recognition to those experiences that are currently underrepresented. In this, we champion a 'zooming in and zooming out' effect; taking the position that geographies of children, youth and families is not only about funnelling or recalibrating our understandings of economic change, but also about opening these effects up to broader scrutiny. Rather than simply "bringing children [youth and families] in" (Morrow, 2012: 6), making them fit into current debates, we suggest that they should be the starting point.

\section{What geographies of children, youth and families can tell us about economic change}

\section{Considering scale}

Firstly, placing the geographies of children, youth and families at the centre of explorations of the everyday brings into focus the liminal spaces where both the transformative and mundane occur. Research focusing on the local, micro-scale realities of children's lives has been critiqued for failing to engage with macro-scale processes and global issues (Ansell, 2009), constraining research involving children, youth and families to the local, everyday environments they inhabit. Over a decade ago, Philo and Smith discuss the necessity for connections to be made between political and children's geographies, with research connecting "the micro-politics of personal experience and the macro-politics of the public sphere" (Philo and Smith, 2010: 110). These intersections between the global and local scales continue to be a focus for sub-disciplinary research exploring politics (broadly conceptualised) in young lives (Benwell and Hopkins, 2016), shifting the focus from dichotomous understandings of the global as universal and local as narrow, to appreciate the multiscalar, entwined nature of economic processes and everyday practices (Holloway and Valentine, 2000).

What we aim to do is in this special issue is contribute to this discussion, bringing analyses of the everyday into conversation with considerations of the current climate of austerity and economic crisis to acknowledge the interlocking scales through which the lives of children, young people and 
their families take place and the centrality of scale for the ways in which individuals and institutions envisage the world (Marston, 2000; Hopkins, 2015). Research within children's geographies has examined this scalar knottiness through attention to both an outward-looking perspective, exploring the interplay between macro political-economic processes and government education policy (Hanson Thiem, 2009), alongside looking inward at the subjects of neoliberal policy restructuring (Holloway et al., 2010). By adopting a multiscalar approach which repositions children, youth and families at the centre rather than at the periphery of discussions about the economy, spanning the breach between the macro and micro scales in analyses of austerity, we might better grasp not only what contemporary and lived experiences of economic transformation feel and look like, but also expose deeper problematics about the geographically and socially uneven nature of neoliberalism and the austere state.

\section{Society-state relations}

Secondly, examining the shifting nature of the economic landscape from the perspective of children, youth and families brings to the fore the effects of macro-economic changes for intimate, everyday geographies. Interweaving explorations of individual and collective responses, resistances and attempts to live through times of economic insecurity can deepen knowledge of the entwined nature of everyday lives, economic processes and austerity measures. Recent attempts to connect the research of political geographers with those examining the geographies of children and youth have underlined the roles, right and positions of youthful actors (e.g. Philo and Smith, 2003; Kallio and Häkli, 2010; Skelton, 2013; Benwell and Hopkins, 2016; Kallio and Mills, 2016). Indeed, in research on young Sikh men's everyday lives in Scotland, Hopkins (2015) interweaves a geopolitical analysis with global political events and national issues to draw attention to scale. Similarly, Staeheli et al. (2013) explore efforts to shape youth citizenship though particular, state-sanctioned political engagements. This growing body of work examining sub-disciplinary intersections of social, cultural 
political and economic geographies provides a springboard to develop a more rounded view of how ordinary lives are intimately bound up with economic processes, which becomes acutely relevant in times of economic change.

Normative frameworks construct youth, and childhood in particular, as a time shielded from adult concerns of politics (Kallio, 2009) and economy (Pimlott-Wilson, 2012b). Yet 'children's worlds' are not separate to those of adults (Kallio and Mills, 2016); rather our lives are interwoven with one another and with economic, social and political processes. In relation to government policy, children and youth are constructed as both the foci of present-day attention and as central to the future of the nation's economy, their everyday lives bound up with economic considerations in multifaceted ways. At the same time as Government spending falls in key areas, including real-terms education expenditure (Cadman, 2015), outcomes for children and young people are increasingly positioned as dependent upon the efforts of individual young people and their families. The intimate spaces of family life simultaneously become a focus for state intervention as both a site which counters the void left by the withdrawal of state support (Haddad, 2012) and where future citizen-workers are produced. The family and (future) citizen-workers thus become the locus for individual failure rather than the market or policy (Boffey, 2016). Attending to the shifting social contract with intimate relationships centre stage brings the repercussions of broad-scale economic shifts and concomitant government policy into sharp relief. Taking a multiscalar approach to explore how global economic insecurity is impacting at the level of the individual, family and neighbourhood can rework our understanding of the broader condition of austerity and associated government policy, recognising the uneven impacts of economic hardship for different household members (Hall, 2016; Pimlott-Wilson, 2015).

In bringing children, youth and families together with considerations of economic change, the significance of temporal geographies becomes apparent. When children and young people receive government attention, it is their latent potential as adult-citizen workers that come under scrutiny. 
This future orientation is implicit in government moves to replace child poverty measures with a focus instead on life chances, including educational attainment, worklessness and addiction. This shift towards an examination of family behaviours directs attention away from material deprivation in the here and now of children's lives, overlooking incidences of income and food poverty resulting from low-paid parental jobs and the varied experiences of economic hardship for different family members (Lambie-Mumford, 2013; Pimlott-Wilson, 2015). Whilst young people's futures are important in analyses of financial change, we cannot overlook the significance of the everyday, nor the past in (re)orientating current pathways. Yet accounts of personal stories must also 'zoom out' to avoid individualising poverty and rather uncover the implications structural problems have for children, youth and families. The daily reality of children's lives cannot be seen as outside of the economic and distinct to that which adults inhabit.

\section{Giving voice and recognition}

Thirdly, a focus on geographies of children, youth and families serves to shed light on the often unremarked lived and experiential accounts of austerity; on the pockets of daily life that are regularly glossed over, and where voices are silent or, worse still, silenced (Matthews, 2003). The rights of children to express their voice and opinion in matters relating to them is enshrined in children's rights discourses and policies (Horton et al, 2008) and acknowledging the voice and agency of youthful research participants is a well-rehearsed refrain in children's geographies (Punch and Tisdall, 2012). Yet within the sub-discipline, critical debates remain as to the desirability of foregrounding the voices of children and young people over maintaining aspects of adult authority (Vanderbeck, 2008; Kraftl, 2013). Indeed, Philo (2011) outlines circumstances where it may be inappropriate to listen to a child's voice, and to instead distil children's narratives through adult frames of knowledge. However, it remains vital to attend to children's voices, particularly when they 
challenge existing (adult) moral codes and normative understandings of childhood (Holloway, 2014). It is also clear that children's narratives (and lives) are not isolated, rather "we must also continue to listen to others (parents, educators, policy-makers, business, etc.) who have the power to shape, or are shaped by, children's lives" (ibid: 382). Positioning children as a social category within broader webs of social relations (cf. Mitchell and Elwood, 2012) whilst simultaneously recognising their role as agential beings, can work to enhance our interpretation of persistent social inequalities and the wide-ranging effects of austerity which (dis)advantage different children.

In economic and financial geography it remains a challenge to lift the lid on the domestic, for instance, and to not just peer inside but actively engage with these private spaces and moments (Wainwright and Kibler, 2014). In particular, listening to participants and garnering such rich and highly personal data necessitates conducting in-depth, qualitative empirical work, making space and time for varying forms of expression. It also means adopting methodological approaches that are conducive to not only dealing with sensitive details, but also engaging different groups and recognising their particular needs. In our own work, for instance, we have shown how research with children and young people needs to engage with the skills and preferences of different participants (Pimlott-Wilson, 2012a), and that socio-economic status influences children's levels of involvement in discussions of familial financial circumstances (Pimlott-Wilson, 2012b). We have also explored the means by which everyday family life might be explored empirically, warning that the intimate relationships within families means that members can accidently expose themselves and their differences to one another in the course of research, which therefore requires careful management (Hall, 2014).

An account of economic change as told by children, youth and families is not only a means of recognising marginalised voices and experiences, but also of appreciating difference, such as within and between families, generations and communities, and between children, youth and families (see Aitken, 1998; Valentine, 2008). Indeed, the impacts of austerity are not, and are unlikely to ever be, 
evenly spread and thus necessitate attending to enduring axes of social difference which exacerbate inequality (Holloway, 2014). As we have been piecing together this collection there have been countless media reports of the unevenness of the recent welfare cuts - argued to have a disproportionate impact on women and children, and poorer families (Grice, 2015; Watt and Perraudin, 2015). It is certainly not the first time that marginal groups have been impacted most by economic change, for a wealth of feminist economic literature has long shown that it is often women in families who bear the effects of financial downturns (Pearson and Elson, 2015). Thus, the lived experiences of such economic change for children, youth and families can be scaled-up, or in our framing 'zoomed out', to speak to a wider political agenda; but it might also be used to question and actively address the uneven impacts of austerity injustice that certain people and social groups experience, as well as how the gaps in care and welfare left by the neoliberal state, in its efforts to privatise and reduce outgoings, might be filled.

\section{A collection, an agenda}

This special section represents a unique and timely collection of essays that for the first time provides a dedicated and focused discussion of the lived experiences of economic change, foregrounding children, youth and families in 'times of austerity'. Using original, empirical material, the papers in this collection address how experiences, perceptions and understandings of the present and the future according to children, youth and families have been shaped by recent economic changes, and likewise how they feel about the future in relation to past and on-going events. These 'futures' may be abstract, experiential, imagined or tangible, and may be individual, collective or inter-generational.

Following this introductory commentary, the collection continues with a paper by Eleanor Jupp, in which she considers the geographies of family, social policy and poverty in the UK in the current 
economic context of austerity. In tracing particular policy formations and elements of welfare reform, particularities are revealed in the construction of family geographies in times of austerity, including the profusion of discourses wielding simplistic and damaging dichotomies, like 'risky' and 'resourceful' families. Similar types of binary thinking have been revealed in other works within this field, such as 'strivers' and 'skivers' (Valentine and Harris, 2014), the deserving and the undeserving (Jensen and Tyler, 2012), each exposing political imaginaries of what family and citizens should be and of the relationship between families and the state. Bridging debates and discussions within social policy and social geography, Jupp argues for the reinvisioning of relationships between families and the state, and posits that one way in which to achieve this might be through considering the spaces 'in between', such as childcare provision; where formalities are often, if not temporarily, suspended and where intimate relationships meet policy changes in practice.

In our second paper, Hannah Lambie-Mumford and Mark Green adopt a child-centred approach to explore the intersections of welfare retrenchment and the growing role of charitable food banks in caring for children. In a context of reduced, conditional welfare support and neoliberal policy emphasis on individual (parental) responsibility for financial provision, they examine intimate consequences of welfare policy transformation as they impinge on the everyday food practices of children. The paper exposes inconsistencies in government rhetoric which on the one hand, seeks to eradicate inequality and child poverty, whilst scaling back state safety nets and overlooking structural causes of poverty. Through 'zooming in' on the food crisis some children experience, Lambie-Mumford and Green shed light on the broad-scale implications of shifting citizen-state relations, structural drivers of poverty and the disproportionate effect of austerity measures for deprived families with children.

Examining young peoples' attitudes to indebtedness, John Horton highlights the interplay between macro-economic processes and young people's everyday geographies. Horton's analysis highlights the normalisation of debt in young peoples' narratives and the growing incidence of current and 
future-anticipated indebtedness for youth over the last decade. The paper charts a shift in participants' attitudes to debt from a strategic trade-off to an unavoidable response to austerity. This interplay between global economic insecurity and the contraction of UK state support has also infused young peoples' anticipated futures with a sense of inevitability in relation to debt; with the inescapability of future debt creating present-day anxieties. Horton's multiscalar analysis thus highlights the interplay between government policy and young peoples' attitudes and anticipations of indebtedness to explore the intimate, emotional consequences of austerity, but also looks outwards to reveal how young people (re)produce normative political-economic logics and narratives of 'economic crisis'.

Examining the connections between neoliberal policy and future aspirations, Helena PimlottWilson's paper explores the emotional geographies of young people's school-to-work transitions. Government rhetoric about the responsible, future-orientated citizen places burdens on young individuals to carve 'successful' future pathways; this paper considers the emotional and affective consequences as young people internalise, and contest, this discourse. In the present, the interplay between the ideals of neoliberal policy, the climate of credentialisation and challenging economic circumstances have consequences for the emotional well-being of young people who strive to achieve the prescribed transition. Moreover, young people express concern for their future emotional state as they navigate increasingly protracted and complex transitions to adulthood. Placing responsibility for future success at the feet of young people is iniquitous in the context of entrenched social inequalities and has emotional consequences for young people as they (re)produce, challenge and resist the individualising rhetoric of aspiration.

Building on this, Clare Holdsworth's paper on 'the cult of experience' goes on to explore the wider politics and regimes that govern present youth futures. In particular, the paper interrogates the desire for experience and differentiation, which are now positioned as essential components in an already-crowded job market, and addresses the contradiction in the commonly-held assumption 
that lack of experience, not lack of jobs, is what is to blame for currently high rates of youth unemployment. Indeed, youth unemployment is one of the most striking, and often banded-about, features of the current period of austerity, and as Holdsworth notes, many young people are finding themselves working in jobs they feel they could have secured without having gone through further education (also see McDowell, 2012). The feeling and affect of this internalisation of responsibility for experience, and often a sense of 'failure', is simultaneously intimate and personal, as well as widely shared amongst young people today.

Continuing this thread of discussion around the intimate and the personal, and drawing on findings from ethnographic research with families in the current period of austerity, Sarah Marie Hall's paper explores the responsibilities of academics doing research in this context. Taking from debates within feminist and moral geographies, and with careful note of the varied experiences of austerity within and between families and communities, she makes the case for understanding the field as a relational space, and fieldwork as a form of care-work. By exploring issues around recompensing participants and the role of personal and relational biographies, she contends that geographies of care and responsibility are intricately woven into the experience of doing research in austerity, which can result in spaces of betweenness and closeness with participants, providing a sharp reminder of the differences between 'living in' and 'living through' austere times.

In her endpiece, Linda McDowell brings together the preceding collection with her own scholarship to argue for a reconfiguration of the gender contract in austere times. The patriarchal sexual contract is unravelling as markers of adult independence are increasingly illusive for young men. The paper highlights the destructive effects to social mobility which result from austerity for children and young people living across the UK, adding further consideration to social class and gender differences which are compounded by economic restructuring. McDowell calls for an expanded research agenda which incorporates children and young peoples' political challenges to neoliberal individualisation. In giving voice to those marginalised by austerity debates, McDowell reminds us of 
the responsibility and pitfalls of representing the lifeworlds of children and young people. As expanded upon in the collection, engaging with youthful participants reveals insight into the intimate, personal implications of austerity for the everyday practices for children and young people; yet ameliorating entrenched inequalities requires concerted academic engagement with policymakers to make these voices heard.

\section{Acknowledgements}

Many thanks to Fiona Nash and to Peter Kraftl as the editorial team, and to Kevin Ward as the former human geography editor for his support of our proposal for this themed issue. We are also most grateful to Sarah Holloway, Sarah Mills and Noel Castree for their comments and thoughts on this paper. Thanks also to all the authors in this special issue for their involvement and excellent contributions, and to those who attended the conference session at the RGS-IBG Annual Conference 2013 where most of these papers were presented and which inspired us to put together this collection. This work is also gratefully supported by Helena's British Academy Postdoctoral Fellowship and Sarah's Hallsworth Research Fellowship from the University of Manchester.

\section{References}

Aalbers, M. (2009) 'The sociology and geography of mortgage markets: Reflections on the financial crisis', International Journal of Urban and Regional Research, 33(2): 281-290.

Aitken, S.C. (1998) Family Fantasies and Community Space, New Brunswick, NJ.: Rutgers University Press.

Ansell, N. (2009) Childhood and the politics of scale: descaling children's geographies, Progress in Human Geography, 33(2): 190-209. 
Benwell, M.C. and Hopkins, P. (2016) Introducing children's and young people's critical geopolitics, Children, Young People and Critical Geopolitics, Ashgate, Abington: 1-27.

Boffey, D. (2016) David Cameron: parents should be taught how to control children. The Guardian, $10^{\text {th }}$ January 2016, http://www.theguardian.com/politics/2016/jan/10/david-cameron-parentschildren-lessons accessed 12/01/2016.

Cadman, E. (2015) Education and development spending due to fall to record low. The Financial Times, $9^{\text {th }}$ November 2015, http://www.ft.com/cms/s/0/068e915a-86f3-11e5-9f8ca8d619fa707c.html\#axzz3xKdiCvYv accessed 20/12/15.

Christophers, B. (2015) 'Geographies of finance II: crisis, space and political-economic transformation', Progress in Human Geography, 39(2): 205-213.

Edwards, R. and Weller, S. (2010) 'Trajectories from youth to adulthood: choice and structure for young people before and during recession', $21^{\text {st }}$ Century Society, 5(2): 125-136.

GOV.UK (2015a) 'Press Release: Government to strengthen child poverty measurement', www.gov.uk/government/news/government-to-strengthen-child-poverty-measure, accessed $13 / 07 / 2015$

GOV.UK (2015b) 'Summer Budget 2015', www.gov.uk/government/publications/summer-budget2015/summer-budget-2015, accessed 13/07/2015.

Grice, A. (2015) 'Budget 2015: George Osborne's tax credit cuts will "affect more than seven million children"', The Independent, 6th July 2015, www.independent.co.uk/news/uk/politics/budget-2015george-osbornes-tax-credit-cuts-will-affect-more-than-seven-million-children-10367585.html, accessed 14/07/2015.

Haddad, M. (2012) The Perfect Storm: Economic stagnation, the rising cost of living, public spending cuts, and the impact on UK poverty. http://policy-practice.oxfam.org.uk/publications/the-perfectstorm-economic-stagnation-the-rising-cost-of-living-public-spending-228591 Hall, S.M. (2014) 'Ethics of ethnography with families: a geographical perspective', Environment and Planning A, 46: 2175-2194. 
Hall, S.M. (2016) 'Everyday family experiences of the financial crisis: getting by in the recent economic recession', Journal of Economic Geography, 16(2): 305-330.

Hanson Thiem, C. (2009) Thinking through education: the geographies of contemporary educational restructuring, Progress in Human Geography, 33(2): 154-73.

Holloway, S.L. (2014) ‘Changing children's geographies'. Children's geographies, 12(4): 377-392.

Holloway S.L., Hubbard, P., Jöns, H., Pimlott-Wilson, H. (2010) Geographies of education and the importance of children, youth and families. Progress in Human Geography, 34(5): 583-600.

Holloway, S.L. and Valentine, G. (2000) Spatiality and the new social studies of childhood. Sociology, 34(4): 763-783.

Hopkins, P. (2015) Scales of young people's lives. In Wyn, J. and Cahill, H. (Eds.) Handbook of Children and Youth Studies. Springer, Singapore: 761-772.

Horton, J., Kraftl, P. and Tucker, F. (2008) 'The challenges of Children's Geographies': an affirmation', Children's Geographies, 6(4): 335-348.

Jensen, T. and Tyler, I. (2012) 'Austerity Parenting: new economies of parent-citizenship', Studies in the Maternal, 4(2): 1-5.

JRF (2012) 'Austerity in the UK', http://www.jrf.org.uk/topic/austerity, accessed 19/11/2012.

Kallio, K.P. (2009) Between social and political: children as political selves, Childhoods Today, 3(2): 1-

22

Kallio, K.P. and Häkli, J. (2010) ‘Children and young people's politics in everyday life', Space and Polity, 17(1): 1-16.

Kallio, K.P. and Mills, S. (2016) ‘Editorial: Geographies of children and young people's politics, citizenship and rights', In Kallio, K.P. and Mills, S. Politics, Citizenship and Rights, Vol. 7 of Skelton, T. (ed.) Geographies of Children and Young People. Springer, Singapore: ix-xviii.

Kraftl, P. (2013) 'Beyond 'voice', beyond 'agency', beyond 'politics'? Hybrid childhoods and some critical reflections on children's emotional geographies', Emotion, Space and Society 9: 13-23. 
Lambie-Mumford, H. (2013) '"Every town should have one": Emergency food banking in the UK', Journal of Social Policy, 42 (1): 73-89.

MacLeavy, J. (2011) 'Reconfiguring work and welfare in the UKs 'new economy': regulatory geographies of welfare-to-work at the local level', Gender, Place and Culture, 18(5): 611-633. Malik, S. (2014) 'The dependent generation: half young European adults live with their parents', The Guardian, 24th March 2014, www.theguardian.com/society/2014/mar/24/dependent-generationhalf-young-european-adults-live-parents, accessed 21/05/2014.

Martin, R. (2011) 'The local geographies of the financial crisis: from the housing bubble to economic recession and beyond', Journal of Economic Geography, 11: 587-618.

Marston, S.A. (2000) The social construction of scale. Progress in Human Geography, 24(2): 219-242. Matthews, H. (2003) 'Coming of Age for Children's Geographies', Children's Geographies, 1(1): 3-5. McDowell, L. (2012) 'Post-crisis, post-Ford and post-gender? Youth identities in an era of austerity', Journal of Youth Studies, 15(5): 573-590.

Mitchell, K. and Elwood, S. (2012) 'Mapping children's politics: the promise of articulation and the limits of nonrepresentational theory', Environment and Planning D, 30(5): 788-804.

Morrow, V. (2012) 'Politics and economics in global questions about childhood and youth... the trouble with numbers', Childhood, 19(1): 3-7.

Oswin, N. and Olund, E. (2010) 'Governing intimacy', Environment and Planning D: Society and Space, 28(1): 60-67.

Oxfam (2013) 'The true cost of austerity and inequality: UK case study', www.oxfam.org/sites/www.oxfam.org/files/cs-true-cost-austerity-inequality-uk-120913-en.pdf, accessed 13/07/2015.

Pain, R. and Smith, S.J. (2008) (Eds.) Fear: critical geopolitics and everyday life. Ashgate, Aldershot. Pearson, R. and Elson, D. (2015) 'Transcending the impact of the financial crisis in the United Kingdom: towards Plan F- a feminist economic strategy', Feminist Review, 109: 8-30. 
Philo, C. and Smith, F. (2003) (Eds.) 'Political geographies of children and young people'. Space and Polity, 7(2): 99-115.

Philo, C. (2011). 'Foucault, sexuality and when not to listen to children'. Children's Geographies, 9(2): 123-127.

Pimlott-Wilson, H. (2012a) 'Visualising children's participation in research: Lego Duplo, rainbows and clouds and moodboards', International Journal of Social Research Methodology, 15(2): 135-148. Pimlott-Wilson, H. (2012b) 'Work-life reconciliation: Including children in the conversation', Geoforum, 43(5): 916-925.

Pimlott-Wilson, H. (2015) ‘Parental responsibility for paid employment and social reproduction: children's experiences in middle class and working class households in England'. Environment and Planning A, 47(9): 1892-1906.

Pollard, J.S. (2013) 'Gendering capital: financial crisis, financialization and (an agenda for) economic geography', Progress in Human Geography, 37(3): 403-423.

Punch, S. and Tisdall, K.M. (2012) 'Introduction: exploring children and young people's relationships across majority and minority worlds', Children's Geographies, 10(3): 241-248.

Skelton, T. (2013) 'Young people, children, politics and space: a decade of youthful political geography scholarship 2003-2013', Space and Polity, 17(1): 123-136.

Stacey, J. (1993) 'Good Riddance to "The Family": A Response to David Popenoe', Journal of Marriage and Family, 55(3): 545-547.

Staeheli, L.A., Attoh, K. and Mitchell, D. (2013) ‘Contested engagements: youth and the politics of citizenship', Space and Polity, 17(1): 88-105.

Valentine, G. (2003) 'Boundary Crossings: Transitions from Childhood to Adulthood', Children's Geographies, 1(1): 37-52.

Valentine, G. (2008) 'The ties that bind: towards geographies of intimacy', Geography Compass, 2(6): 2097-2110. 
Valentine, G. and Harris, C. (2014) 'Strivers vs skivers: Class prejudice and the demonisation of dependency in everyday life', Geoforum, 53: 84-92.

Vanderbeck, R.M. (2008) 'Reaching critical mass? Theory, politics, and the culture of debate in children geographies', Area, 40(3): 393-400.

Wainwright, T. and Kibler, E. (2014) 'Beyond financialization: older entrepreneurship and retirement planning', Journal of Economic Geography, 14: 849-864.

Watt, N, and Perraudin, F. (2015) 'Cuts to tax credits in budget hit women twice as hard as men, says Labour', The Guardian, 8th July 2015, www.theguardian.com/uk-news/2015/jul/08/budget-child-taxcredit-cuts-affect-women-worse-men-labour-yvette-cooper, accessed 14/07/2015. 